\title{
POLITISKĀ LIBERĀLISMA NOVĒRTĒJUMS LATVIJĀ
}

\author{
Juris Pupčenoks, Dr. phil., asociētais profesors, Marista Koledža, ASV
}

2018. gadā izdotā Daces Dzenovskas grāmata (School of Europeanness: Tolerance and Other Lessons in Political Liberalism in Latvia. Ithaka, NY : Cornell University Press) ir jau tikusi augstu novērtēta ārpus Latvijas. Baltijas studiju veicināšanas apvienība ( $A s$ sociation for the Advancement of Baltic Studies - AABS) tai pasniedza 2020. gada labākās grāmatas balvu. Prominentais žurnāls Foreign Affairs, kas selektīvi recenzē tikai tās zinātniskās grāmatas, kuras tas uzskata par pašām ietekmīgākajām, raksta, ka ir jāpievērš uzmanība D. Dzenovskas kritikai, ka palielināta migrācija ir veicinājusi labējā nacionālisma pieaugšanu Eiropā un ASV, tālāk graujot Rietumu liberālisma pretenzijas uz morālo un politisko pārākumu. ${ }^{1}$ Lai arī autore specializējas politiskajā antropoloǵijā, šī grāmata interesēs pētniekus arī vairākās citās disciplīnās, ieskaitot politikas zinātni, vēsturi un filozofiju. Tā būs interesanta arī praktiķiem. Grāmatā tiek lietota gadījuma izpēte (reformas un veiktās darbības Latvijā politiskā liberālisma vārdā laika posmā pēc aukstā kara beigām), lai kritizētu politiskā liberālisma konceptualizāciju.

Vienlaikus D. Dzenovska atzīst, ka viņas galvenais mērḳis nav radīt vēl vienu grāmatu, kas kritizētu politisko liberālismu. Tā vietā pētniece vēlas parādīt, ka Rietumu koncentrēšanās uz "vēstures beigu" (the end of history) tēzi un draudi, ko Austrumeiropā varētu radīt politiskā liberālisma kritika, ir aizēnojušas esošās varas hierarhijas, kas veido Eiropas tagadni (18). Tipiski, ka Rietumu

1 Lipman, Maria (2019) Book Review of School of Europeanness by Dace Dzenovska. Foreign Affairs, September/October. Pieejams: https:// www.foreignaffairs.com/reviews/capsule-review/2019-08-12/school-europeanness-tolerance-and-other-lessons-political. politiskā liberālisma mācības Latvijai un citām Austrumeiropas valstīm ir tikušas konsekventi formulētas kā "tuvināšanās Eiropai", kur cilvēki ir demokrātiskāki, politiski nobriedušāki un arī iecietīgāki (10). Vienlaikus arī daudzi Rietumu politiskā liberālisma atbalstītāji uzsver, ka Austrumeiropā trūkst š̄ liberālisma. D. Dzenovska argumentē, ka, tā vietā, lai jautātu, vai latvieši un austrumeiropieši ir vai nav iecietīgi un toleranti, ir jājautā, kādi ir iekļaušanās ierobežojumi mūsdienu Eiropas sabiedrībās - un kādas sekas no tā izriet mūsu izpratnei par politisko liberālismu (13). Ir nepieciešams arī analizēt, kā Eiropas sabiedrībās notiek cilvēku un grupu iekḷaušana un izslēgšana morālu apsvērumu dēḷ.

Galvenais D. Dzenovskas arguments par Latviju ir nozīmīgs akadēmiskajā literatūrā, ieskaitot literatūru par politisko liberālismu, postkoloniālismu un postsociālismu, bet tas nebūt nebūs pārsteidzošs viduvējam Latvijas iedzīvotājam. Grāmata pārliecinoši argumentē, ka politiskā liberālisma atbalstītāji Latvijas vēlmē pievienoties brīvajai pasaulei nepievērsa pietiekamu uzmanību ǵeopolitikai, kā arī nepareizi interpretēja vēstures un kultūras nozīmi. Daudzi latvieši ne vienmēr ticēja politiskā liberālisma atbalstītāju idejai par Eiropu un tās vērtībām, bet gan vēlējās, lai Latvija integrētos Eiropā un piedalītos tādās drošības aliansēs kā NATO, lai pārliecinātos, ka vēsture neatkārtojas. Reizēm svarīgas zinātniskas inovācijas notiek tādā veidā, ka vienā disciplīnā jau zināmi atklājumi kā svarīgi jauninājumi tiek pārnesti uz citu disciplīnu. Līdz zināmai robežai tas notiek arī šajā grāmatā. D. Dzenovska plašākā politiskā liberālisma literatūrā integrē atklājumus, kas bija jau samērā labi zināmi pētniekiem, kuri pēta Latviju (ka Latvijas vēlēšanos pievienoties brīvajai pasaulei lielā mērā veicināja drošîbas apsvērumi, nevis 
vēlme apgūt un pieņemt politiskā liberālisma vērtības), un šajā procesā pievieno vēl ko jaunu un svarīgu.

Dažādās grāmatas nodaḷās analizēts, kā Latvijas iedzīvotāji dzīvo eiropeiskuma paradoksā, kas prasa dažādu grupu vienlaicīgu iekļaušanu un izslēgšanu. Pirmās divas nodal̦as lielā mērā pievērš uzmanību vēstures ietekmei. Pirmā nodaḷa koncentrējas uz Eiropas (un Latvijas) koloniālās vēstures iespaidu uz mūsdienu uzskatiem. Pētniece parāda Latvijas paradoksu - no vienas puses, latvieši atzīst brīvību, cilvēktiesības un demokrātiju, bet, no otras puses, arī izrāda lepnumu par koloniālismu attiecībā uz 17. gadsimta Kurzemes hercogistes kolonijām Tobago un Gambijā (23). Kamēr vairums bijušo Eiropas koloniālo valstu jūt kaunu par koloniālo mantojumu, Latvija par to izrāda lepnumu. Latvieši identificējas ar koloniālajām uzvarām, vienlaikus distancējoties no koloniālajiem ievainojumiem. D. Dzenovska skaidro, ka vēsturiski šis lepnums bijis veids, kā latvieši varēja parādīt, ka ir bijuši vairāk nekā tikai dzimtcilvēki. Latviešu lepnums par bijušajām un īslaicīgajām kolonijām Tobago un Gambijā ir arī veids, kā latvieši var atklāt mazās Latvijas vēsturisko ietekmi uz pasaules politiku. Otrā nodaḷa koncentrējas uz attiecību atspoguļojumu starp latviešiem un krievvalodīgajiem 20. un 21. gadsimtā. Tā parāda, ka vēsturisku iemeslu dēl nevis tolerance, bet gan integrācija ir jēdziens, kas regulē attiecības starp latviešiem un krievvalodīgajiem Latvijā.

Grāmatas pārējās nodaḷas fokusējas uz to, ko autore sauc par "tolerances darbinieku" (tolerance workers) darbu un dažādiem iekḷaušanas un izslēgšanas gadījumiem latviešu sabiedrībā. Trešā nodaḷa aplūko, kā dažādi tolerances darbinieki (piem., vai nu valsts, vai nevalstisko organizāciju darbinieki) ir mēgeinājuši kultivēt Latvijā toleranci un iecietību kā politisko vērtību. Lai gan šie darbinieki piekrita, ka pastāv problēma, viṇi ne vienmēr vienojās par nepieciešamajām kontūrām un intervencēm, kā arī vēlamajiem rezultātiem. Tolerances darbinieki (ceturtā nodaḷa) uzskatīja, ka lielākā problēma Latvijā bija nespēja atzīt neiecietību, kā iemeslu saredzot plaši izplatīto kritiskās domāšanas trūkumu un vispārēju nevēlēšanos iesaistīties kritiskās sabiedriskās pārdomās (112).

Piektā nodaḷa apskata mēgināājumus pārliecināt sabiedrību nelietot aizskarošos vārdus "nēǵeris" un “žīds”. Sestā nodaḷa pievērš uzmanību Latvijas fiziskajām robežām un parāda, kā dažādi lēmumi par to, kādā veidā regulēt robežas un migrāciju, reprezentēja spriedzi starp atvērtību un slēgšanu un kā latviešu sabiedrībai vajadzēja savstarpēji runāt un vienoties par šiem jautājumiem, lai kḷūtu par eiropeisku sabiedrību (177). Nodaḷas beigās D. Dzenovska lielā mērā apkopo sava darba galvenos punktus: "Institucionalizētā politiskā liberālisma formas nav spējušas atzīt un pievērsties vēsturiskā un kultūras ziņā iesakņojušos subjektu sūdzībām, kuri piedzīvo atsvešināšanos postsociālisma pārvērtību rezultātā" un sociālekonomiskā stāvokḷa pasliktināšanos (206).

Grāmata ir metodologiski spēcīga un piedāvā plašu pieeju tolerances pētī̌sanai, īpaši inovatīva tā ir Latvijas koloniālisma vēstures novērtējumā, tajā iespaidīgi lietoti spilgti stāsti, lai ilustrētu dažādus punktus. Metodoloǵiskā ziņā šî grāmata ir l̦oti bagāta: piem., pētniece izmanto datus no intervijām, etnogrāfiskiem novērojumiem, fokusa grupām un publiskās domas aptaujām. Ir vērtīgi, ka tā sniedz plašāku skatījumu uz toleranci Latvijā un pievēršas arī citām grupām (ieskaitot citu rasu cilvēkus un cilvēkus ar dažādu seksuālo orientāciju) nekā tikai krievvalodīgajiem. Tikpat vērtīgi un inovatīvi, ka grāmata velta veselu nodaḷu analīzei, kā Latvijas koloniālais mantojums ir ietekmējis uzskatus par toleranci. Visbeidzot, D. Dzenovska ir lieliska stāstītāja - viņas spilgtie stāsti par dažādām tikšanās reizēm ar latviešiem spoži atdzīvojas un palīdz ilustrēt paustos analītiskos secinājumus. Piem., koloniālisma nodaḷā mēs lasām par Jāni, kurš dodas uz Gambiju meklēt pēdas Kurzemes hercogistes perioda latviešu dzimtcilvēkiem, šis stāsts ilustrē vēlmi redzēt latviešus ne tikai kā strādnieku masu, bet arī kā vēstures pārmainuu aǵentus. Noslēgumā jāuzsver, ka šī grāmata sniedz vērtīgu ieguldījumu vairākās akadēmiskās jomās un tās autore autoritatīvi novērtē Latvijā veiktās politiskā liberālisma reformas pēc aukstā kara. 